\title{
KORUPSI DALAM PERSPEKTIF ALQURAN
}

\author{
Budi Birahmat \\ Sekolah Tinggi Agama Islam Negeri (STAIN) Curup \\ e-mail: al_fajry08@yahoo.com
}

\begin{abstract}
Abstrak
Artikel ini bertujuan untuk menelusuri tinjauan Alquran terhadap tindak pidana korupsi. Karena salah satu persoalan yang sedang marak terjadi di Indonesia saat ini adalah kejahatan terhadap tindak pidana korupsi, berbagai cara sudah dilakukan Negara untuk mengatasi tindak pidana korupsi, mulai dari merobah undang-undang, mendirikan lembaga yang khusus menangani tindak pidana korupsi sampai kepada meningkatkan sangsi bagi terpidana korupsi, akan tetapi hal ini masih berlum menapakkan hasil yang mengembirakan masyarakat. Data yang disajikan dalam tulisan ini bersumber dari kajian kepustakaan dengan menelusuri sumber-sumber yang berhubungan langsung dengan tema terutama Alquran dan sunnah. Dari hasil penelitian ini ditemui bahwa: Korupsi sebagai sebuah tindak kejahatan extra-ordinary crimes memang tidak disebut secara eksplisit oleh Alquran, tetapi beberpa term seperti ghulul, suht, sarq, hirabah beberapa term tersebut dirasa cukup mewakili gagasan Alquran mengenai tindak korupsi. Hukuman bagi pelaku korupsi, yang paling cocok menurut penulis adalah hukuman jarimah ta'dzir yang dalam pelaksanaannya mungkin menyamai atau bahkan melebihi sanksi hukuman hadd. Dalam hal ini penguasa diberi kekuasaan untuk menentukan hukuman-hukuman sesuai kepentingan masyarakat, dan tidak boleh bertentangan dengan ketentuan-ketentuan syari'at dan prinsip-prinsip yang umum, seperti menerapkan UU Nomor 31 Tahun 1999 dan yang telah disempurnakan oleh UU Nomor 20 Tahun 2001 Tentang Pemberantasan Tindak Pidana Korupsi.
\end{abstract}

Kata kunci: Korupsi, kejahatan luar biasa, perspektif Alquran

\begin{abstract}
This article aims to track the Qur'an review of corruption. Because one of the most prevalent issues in Indonesia today is criminal acts of corruption, various ways have been done by the State to overcome corruption, from changing the law, establishing an institution specifically dealing with corruption to increase
\end{abstract}

FOKUS : Jurnal Kajian Keislaman dan Kemasyarakatan Vol. 3, no. 1, 2018

P3M Sekolah Tinggi Agama Islam Negeri (STAIN) Curup-Bengkulu

Available online: http//journal.staincurup.ac.id/index.php/JF

p-ISSN 2548-334X. e-ISSN 2548-3358 
the sanction for convicted of corruption, but it is still not yet yielding results that encourage the community. The data presented in this paper is sourced from literature review by tracing the sources directly related to the theme especially the Qur'an and Sunnah. From the results of this study found that: Corruption as an extra-ordinary crimes crime is not explicitly mentioned by the Qur'an, but some terms such as ghulul, suht, sarq, hirabah some terms are considered to represent the Qur'an's notion of corruption. The punishment for the perpetrators of corruption, the most appropriate according to the authors is the punishment of the ta'dzir finger which in its implementation may equal or even exceed the sanction of hadd penalty. In this case the rulers are given the power to determine punishments according to the public interest, and should not be contrary to the provisions of shari'ah and general principles, such as applying Undang-undang No. 31 Tahun 1999 and which has been perfected by Undang-undang Nomor 20 Tahun 2001 Tentang Pemberantasan Tindak Pidana Korupsi.

Keywords: Corruption, extra-ordinary crimes, Quranic perspectives

\section{PENDAHULUAN}

Problem sosial yang terus diperbincangkan tiada henti saat ini adalah kasus korupsi yang kian memprihatikan. Perbincangan problematika korupsi hampir menemui jalan buntu karena apa yang dijadikan langkah pemberantasan korupsi di negeri ini berbanding terbalik dengan terus meningkatnya indeks peringkat korupsi di Indonesia. Oleh karenanya, banyak masyarakat yang lebih bersifat pesimis terhadap langkah pemberantasan korupsi di Indonesia, bahkan di antaranya sudah ada yang bersifat permisif. Selain itu, Korupsi juga merupakan kejahatan yang tergolong extra-ordinary crimes (kejahatan sangat berat), sama halnya dengan terorisme yang secara akademis dikategorikan sebagai kejahatan luar biasa (extra ordinary crime). Dengan demikian maka pemberantasannya tentulah tidak dapat menggunakan cara-cara yang biasa sebagaimana menangani tindak pidana biasa seperti pencurian, pembunuhan, serta penganiayaan. ${ }^{1}$ Korupsi di Indonesia terjadi secar sistimatis dan meluas, sehingga tidak hanya merugikan keuangan Negara, tetapi juga telah melanggar hak-hak social dan ekonomi masyarakat secara luas, maka pemberantasan tindak korupsi harus dilakukan dengan cara luar biasa.

${ }^{1}$ Asmara, M. (2016). Reinterpretasi Makna Jihad Dan Teroris. Al-ISTINBATH : Jurnal Huk.um Islam, 1(1), 63-80. doi:http://dx.doi.org/10.29240/jhi.v1i1.87 
Berangkat dari problematika di atas, sebagian cendekiawan mulai melacak penegasan Alquran mengenai korupsi. Hal itu dilakukan sebagai upaya menemukan epistemologi pemberantasan kasus korupsi mengingat bahwa Alquran adalah kitab suci yang memberikan petunjuk. Sementara itu, Alquran, yang masih bersifat global dan universal, menyisakan permasalahan yang harus dicermati dan dikaji secara komperhensif.

Melalui tulisan ini, penulis mencoba melihat pandangan Alquran tentang korupsi dengan cara melacak beberapa ayat terindikasi tentang topik korupsi dengan menggunakan metode tematik atau yang populer dengan istilah 'maudhu' $i$ ' dengan pendekatan ontologis sehingga menemukan hakikat makna dan esensi dari segala sesuatu. Kemudian dikaitkan dengan tinjauan fiqh untuk menemukan jawaban hukumnya. Bukan maksud penulis menjustifikasi bahwa rumusan fiqh ini sebagai bentuk supremasi hukum yang harus diterapkan, karena hemat penulis tentu hal itu akan memicu problematika lain di negeri yang multi agama ini. Harapan penulis melalui tulisan ini hanya sebagai sebuah nilai tawar terhadap dinamika wacana pemberantasan korupsi.

Kata 'korupsi' berakar pada bahasa latin corruption atau dari kata asal corrumpere. Secara etimologi, dalam bahasa Latin kata corruption bermakna busuk, rusak, menggoyahkan, memutar balik, dan menyogok. ${ }^{2}$ Sedangkan dalam bahasa Inggris, kata corrupt bermakna orang-orang yang memiliki korupsi berkeinginan melakukan kecurangan secara tidak sah untuk memperoleh keuntungan-keuntungan pribadi. $^{3}$

Dalam bahasa Perancis juga dikenal dengan kata corruption, sementara dalam bahasa Belanda dikenal dengan sebutan corruptie (korruptie). Menurut Andi Hamzah bahwa kata korupsi yang sampai dan sering dipakai dalam bahasa Indonesia merupakan plagiasi dari kata korruptie dalam bahasa Belanda. ${ }^{4}$

Secara terminologis banyak ahli memiliki definisi masing-masing. Robert Klitgaard mendefinisikan "corruption is the abuse of public power for private benefit", korupsi adalah penyalahgunaan kekuasaan publik untuk keuntungan pribadi. Korupsi juga berarti memungut uang bagi layanan yang sudah seharusnya diberikan, atau menggunakan wewenang untuk mencapai tujuan yang tidak sah. ${ }^{5}$

\footnotetext{
${ }^{2}$ Bambang Soesatyo, Perang-perangan Melawan Korupsi, (Jakarta: Ufuk Press, 2011): 24.

3Jonathan Crowther (ed), Oxford: Advanced Learners Dictionary (1995): 247

${ }^{4}$ Andi Hamzah, Pemberantasan Korupsi Melahi Hukum Nasional dan Internasional, Jakarta: Raja Grafindo Persada, 2005): 4.

${ }^{5}$ Robert Klitgaard dkk., Penuntun Pemberantasan Korupsi dalam Pemerintahan Daerab terj. Hermoyo, (Jakarta: Yayasan Obor Indonesia, 2002): 3.
} 
Namun pada prinsipnya pendekatan yang dapat dilakukan terhadap masalah korupsi memiliki titik tekan yang beragam sesuai dengan perspektif dan sudut pandang keilmuan yang dipakai. Dalam perspektif sosiologis misalnya Alatas dalam bukunya The Sociology of Corruption, memasukkan nepotisme dalam kelompok korupsi dalam pengertian 'memasang keluarga atau teman pada jabatan tertentu dalam pemerintahan tanpa memenuhi syarat untuk itu'. Jika hal ini dipakai tentulah tidak akan ditemukan makna dan normanya dalam perspektif hukum pidana. ${ }^{6}$ Arti ini tentu berbeda jika dipakai perspektif politik atau ekonomi.

Berbagai definisi yang dikemukakan oleh para ahli, Sayyid Husain al-Alatas menyimpulkan bahwa korupsi tidak akan lepas dari beberapa ciri khususnya, yaitu: (a) suatu pengkhianatan terhadap kepercayaan, (b) penipuan terhadap badan pemerintahan, lembaga swasta atau masyarakat umum, (c) dengan sengaja melalaikan kepentingan umum untuk kepentingan khusus, (d) dilakukan dengan rahasia, (e) melibatkan lebih dari satu orang atau pihak, (f) adanya kewajiban dan keuntungan bersama, (g) terpusatnya kegiatan korupsi pada mereka yang menghendaki keputusan yang pasti dan mereka yang dapat mempengaruhinya, (g) adanya usaha untuk menutupi perbuatan korup dalam bentuk pengesahan hukum, (i) menunjukkan fungsi ganda pada setiap individu yang melakukan korupsi. ${ }^{7}$

Sejarah mengenai korupsi sendiri memang cukup panjang. Menurut petunjuk Hans G. Guterbock, catatan kuno mengenai masalah ini menunjuk pada penyuapan terhadap hakim dan tingkah laku para pejabat pemerintah. Dalam sejarah Mesir, Babilonia, Ibrani, India, Cina, Yunani dan Romawi Kuno, korupsi seringkali muncul ke permukaan sebagai masalah.

Dalam sejarah Islam sendiri, korupsi pada masa nabi SAW sudah pernah terjadi, di antaranya kisah Karkirah yang diriwayatkan oleh al-Bukhari sebagai berikut:

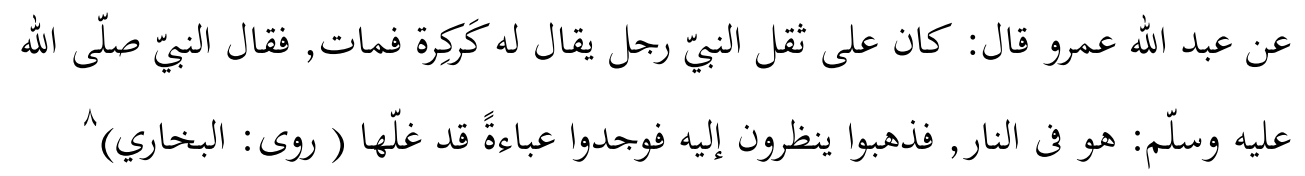

Dari Abdullah ibn Amr ra, ia berkata: "Ada seseorang yang bernama Karkirah, yaitu pembawa barang-barang Nabi SAW, ia mati dalam peperangan, lalu Nabi mengatakan: "ia masuk neraka". Kemudian para sahabat memeriksanya, ternyata mereka mendapatkan sehelai pakaian yang ia korup dari ghanimah". (HR: alBukhari)

${ }^{6}$ M. Nurul Irfan, 2011, Korupsi dalam Hukum Pidana Islam, (Jakarta: Amzah, 2011): 35. ${ }^{7}$ S.H. Al-Alatas, Korupsi; Sifat, Sebab dan Fungsi terj. Nirwono, (Jakarta; LP3ES, 1987): 2. ${ }^{8} \mathrm{CD}$-ROOM, al-Makbtabah al-Syamilah, No. Hadis 2845. 
Karkirah seorang yang suka membawakan barang Nabi ketika perang, ketika ia wafat Nabi memponisnya masuk neraka, bahkan Nabi enggan menshalati jenazahnya dan menyuruh para sahabat untuk menshalainya. Para sahabat bertanyatanya, apa gerangan yang membuat semua amalnya sia-sia? Ternyatan, ia menyembunyikan sehelai pakaian ghanimah yang belum dibagi bagian-bagiannya. Atau dalam riwayat Abu Daun; perhiasan yang beratnya tidak mencapai 2 dirhampun.

Pada era kekuasaan Khulafâ al-Râsyidîn tepatnya pada masa Umar bin alKhattab juga telah ditemui upaya praktek korupsi. Hal ini dikuatkan dengan usaha Umar memerintahkan seorang sahabat yang bernama Maslamah untuk mengawasi harta kekayaan para pejabat pemerintah. ${ }^{9}$

Dengan melihat beberapa fakta sejarah tersebut, maka sebetulnya pada masa Arab 'Era Alquran' kasus korupsi sudah ditemukan. Namun, seperti penulis tuturkan di muka, Alquran tidak mengemukakan ayat korupsi secara eksplisit. Bahkan secara tegas Ahmad Baidlawi menyebut bahwa dalam Islam, dalam konteks ini Alquran, kasus korupsi tidak diuraikan secara jelas. ${ }^{10}$

Memang di dalam Alquran tidak dijumpai istilah korupsi secara tegas, namun untuk menyelesaikan kasus ini ada beberapa ayat yang terindikasi tentang itu. Di antaranya:

\section{Surat Ali-Imran ayat 161}

"Tidak mungkin seorang nabi berkhianat dalam urusan harta rampasan perang. Barangsiapa yang berkhianat dalam urusan rampasan perang itu, maka pada hari kiamat ia akan datang membawa apa yang dikhianatkannya itu, kemudian tiap-tiap diri akan diberi pembalasan tentang apa yang ia kerjakan dengan (pembalasan) setimpal, sedang mereka tidak dianiaya." (QS.3:161)

\section{Asbab al-Nuzul}

Sebab turunnya ayat ini, sebagaimana hadits riwayat Ibn Abbas ra. Bahwa setelah masa perang Badar, ada seorang laki-laki yang kehilangan tutup kepala berwarna merah. Lalu ada seseorang yang menuduhkan bahwa Nabilah yang mengambilnya, maka ayat turun untuk membantahnya sekaligus sebagai khabar bahwa setiap Nabi tidak akan pernah mencuri/ korupsi.

\section{Tafsiran Ayat}

Dalam Ayat ini ada istilah ' $g$ hulul' yang berrarti penghianatan. Menurut alMaraghi dalam tafsirnya, Tafsir al-Maraghi, menjelaskan bahwa kata ghulul dalam ayat itu bermakna 'al-akhdz al-khufiyyah', yaitu mengambil sesuatu dengan

\footnotetext{
${ }^{9}$ Muhammad Husain Haikal, Sayyidina Umar bin Khattab, Jakarta: Litera Antar Nusa, 2003): 665 .

${ }^{10}$ Ahmad Baidlawi, "Pemberantasan Korupsi dalam Persepektif Islam", dalam Jurnal Esensia, Vol. 10, No. 2, Juli, 2009: 8.
} 
sembunyi-sembunyi, semisal mencuri sesuatu. Kemudian makna ini sering digunakan dalam istilah mencuri harta rampasan perang sebelum didistribusikan. ${ }^{11}$

Rasulullah SAW sendiri memperluas makna ghulul menjadi dua bentuk:

1. Komisi, yaitu tindakan mengambil sesuatu penghasilan di luar gaji yang telah diberikan. Tentang hal ini Nabi SAW menyatakan:

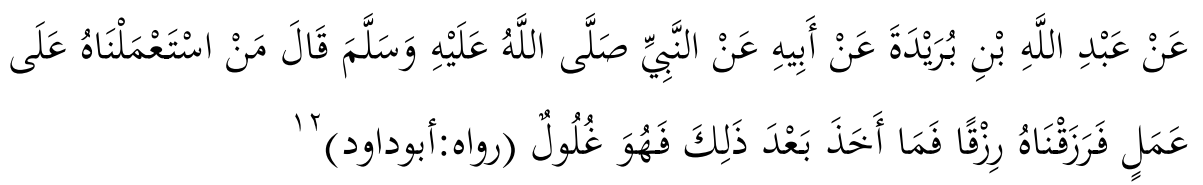

Rasulullah SAW bersabda: Barang siapa yang kami angkat menjadi pegawai pada suatu pekerjaan kemudian kami tetapkan gaji tertentu untuknya, maka apa yang dipungutnya sesudah itu adalah kecurangan (korupsi). (HR.Abu Daud)

2. Hadiah, yaitu pemberian yang didapatkan seseorang karena jabatan yang melekat pada dirinya. Mengenai hal ini Rasulullah SAW bersabda "Hadiah yang diterima para pejabat adalah korupsi (ghulul)”.(HR. Ahmad) ${ }^{13}$

Quraisy Syihab dalam tafsirnya al-Misbah mengungkapkan bahwa senyatanya pengkhianatan yang disebutkan dalam ayat initerjadi pada saat perang Uhud. Perang Uhud adalah suatu kejadian di mana muslimin mengalami kekalahan. Salah satu faktor kekalahan tersebut disinyalir adalah kerakusan sahabat yang kemudian menghambur ke bawah gunung untuk mengambil harta rampasan perang.

Dengan tindakannya ini, mereka berarti juga telah mengkhianati komando Rasulullah SAW untuk tetap berada di atas gunung apapun yang terjadi. Strategi ini adalah taktik utama Rasulullah SAW untuk memenangkan perang dengan jumlah pasukan dan logistik yang tidak seimbang antar kedua belah pihak. Pada dasarnya, selain dilatarbelakangi rasa rakus, mereka juga khawatir Rasulullah SAW tidak akan memberikan pembagian harta rampasan perang dengan adil kepada para prajurit. Lebih lanjut Quraisy menambahkan bahwa padanan kata dari al-ghulul di sini adalah lafadz al fadhihah, yakni melakukan sesuatu yang mencemarkan nama baik dan memalukan.

Ayat ini juga menegaskan bahwa seorang Nabi (terlebih Nabi Muhammad SAW) tidak akan melakukan suatu penghianatan, sebab hal tersebut bertentangan dengan sifat amanah Nabi. Dengan demikian, khianat dalam ayat ini juga berarti khianat secara umum, semisal dalam mengemban

\footnotetext{
${ }^{11}$ Al-Maghari, Tafsir al-Maraghi, (Bairut: Dar al-Kutub al-Ilmiyyah, 2006): 98.

${ }^{12} \mathrm{CD}$-ROOM, No. Hadis. 2554

${ }^{13}$ Ahmad Baidlawi, 2009: 4.
} 
amanah publik (misalnya jabatan) atau amanah antar individu (misalnya dititipi barang atau pesan untuk disampaikan pada orang lain). ${ }^{14}$

Jika dibandingkan dengan beberapa term lainnya, katagori ghulul ini memiliki titik tekan kepada suatu penghianatan atas amanah yang telah dipercayakan. Penghianatan ini secara umum terkait dengan suatu amanah (jabatan) dan memang memiliki arti luas, akan tetapi yang dimaksud di sini adalah penghianatan dalam hal harta benda.

Perbuatan ghulul ini hukumnya adalah haram dan mereka harus memertanggungjawabkan sesuatu yang telah disembunyikannya. Seorang mufassir bahkan menyebutkan bahwa di akhirat, seseorang yang telah menggelapkan sesuatu akan memanggul sesuatu yang pernah disembunyikannya sehingga tidak bisa disembunyikan lagi dan diketahui oleh semua orang. ${ }^{15}$

\section{Surat al-Baqarah ayat 188}

"Dan janganlah sebahagian kamu memakan harta sebahagian yang lain di antara kamu dengan jalan yang batil dan (janganlah) kamu membawa (urusan) harta itu kepada hakim, supaya kamu dapat memakan sebahagian daripada harta benda orang lain itu dengan (jalan berbuat) dosa, padahal kamu mengetahui." (QS.2:188)

\section{Asbab al-Nuzul}

Sebab turun ayat tersebut dijelaskan Ibn Katsir dalam tafsirnya melalui khabar dari jalur Ibn Abbas mengatakan bahwa ayat ini berkenaan dengan seorang laki-laki yang menanggung hutang, sedangkan orang yang memberi hutang tidak mempunyai bukti yang kuat (ketika ingin menagih hutang tersebut). Maka laki-laki yang mempunyai hutang tersebut mengingkari hutangnya dan mengadukan perkaranya pada hakim, padahal dia mengetahui bahwa dia berhadapan dengan perkara yang hak, dan bahwa dirinya berada dalam pihak yang salah.Setting historis inilah yang kemudian direspons oleh Alquran dengan turunnya ayat tersebut yang secara tegas melarang seseorang untuk memakan harta orang lain dan memperjuangkan sesuatu yang batil. ${ }^{16}$ Karena itu, Islam melarang keras membawa urusan harta benda kepada hakim bila hal yang melatarbelakangi adalah kebatilan.

\footnotetext{
${ }^{14}$ Quraisy Syihab, Tafsir al-Misbah, (Jakarta: Lentera Hati, 2002):

${ }^{15}$ Hafidz Dasuki (dkk.), al-Qur an dan Tafsirnya, (Yogyakarta: UII Press, 1991): 77.

${ }^{16} \mathrm{Ibn}$ Katsir, Tafsir Alquran al-Karim, Terj. Salim Bahraesi dan Said Bahraesi,(Surabaya: Bina Ilmu, 1986), Jilid II: 226.
} 
Dalam Ensiklopedi Alquran diceritakan asbabunnuzul ayat ini bahwa pada suatu hari, ada dua orang yang saling berseteru dan sama-sama mengaku bahwa merekalah pemilik sah sebuah tanah. Namun, keduanya tidak memiliki saksi dan bukti yang bisa menguatkan pengakuannya. Karena proses ini cukup alot, maka hakim memerintahan kedua belah pihak untuk sama-sama bersumpah. Mereka berdua sama-sama bersumpah. Namun salah satu dari mereka, yakni orang yang bernama Imrìi Qays memberikan sumpah palsu. Karena itulah, ayat ini kemudian turun. Hal ini juga berkait erat dengan kebiasaan masyarakat saat itu (mungkin juga saat ini) yang menjadikan pengadilan sebagai media penyelamat untuk membela mereka yang sebenarnya berada pada pihak yang salah. Ironi ini disebabkan menjamurnya mafia peradilan. Di pengadilan, orang yang pandai bersilat lidah dan memiliki dana cukup, sangat dimungkinkan bisa memenangkan kasus meskipun berada dalam pihak yang salah. Hal ini merupakan outcome dari praktik menyogok hakim, pengacara, dan orang-orang yang berkecimpung dalam lembaga peradilan. ${ }^{17}$

\section{Tafsiran Ayat}

Ayat ini menggunakan term addalwu (jama dari dalyun )- al idla ${ }^{18}$ Pada dasarya, arti dari kata ini adalah menurunkan timba untuk mengambil air. Thaba` Thabai menambahkan bahwa pengertian menurunkan timba ke dalam sumber yang tujuannya mendapatkan air tersebut sama halnya dengan praktik suap yang dilakukan secara sembunyi. Sebagaimana diketahui bahwa ketika sebuah timba dimasukkan ke dalam sumur, maka orang lain tidak bisa melihatnya. Secara otomatis, orang lain juga tidak tahu bahwa ada timba yang berusaha mengambil air (manfaat) dari sumur tersebut. Hal ini sama dengan keadaan praktik suap yang memang sengaja disamarkan dari publik agar tujuan suap tersebut tetap off the record. ${ }^{19}$

Jika dibaca dalam konteks korupsi, mengandung makna yang sangat tegas melarang memakan harta orang lain dengan jalan yang tidak dibenarkan oleh agama (al-bathil). Makna yang dimaksud dalam ayat tersebut adalah menyuap hakim, kadi, dan lain sebagainya yang memiliki kekuasaan untuk membebaskan sang penyuap dari tuntutan sesuatu. ${ }^{20}$

${ }^{17}$ Chamamah Suratno (ed), Ensiklopedi al-Qur'an: Dunia Islam Modern, (Yogyakarta: Bhakti Prima Yasa, 2003): 401.

${ }^{18}$ Chamamah, 2003: 400.

${ }^{19}$ Thaba`Thaba i, Tafsir al-Mizan, (Beirut: Yayasan al-I'lami, [t.th]), Juz 2: 52.

${ }^{20}$ Al-Maghari,2006: 255. 
Satu contoh dari praktik bathil tersebut, yakni menyuap seorang hakim dengan tujuan agar hakim tersebut melakukan suatu hal yang diperintahkan-dan tentunya menguntungkan-bagi si penyuap. Padanan kata dari term ad-dalwu ini adalah ar-risywah. Ironisnya, seperti disebutkan dalam teks ayat ini, orang yang disuap menyadari bahwa pemberi suap tersebut berada dalam pihak yang salah. Namun, karena mendapatkan uang suap, hakim yang menerima suap tersebut kemudian membohongi hati nuraninya sendiri dan menggunakan kemahirannya untuk membela orang yang salah.

Praktik mafia peradilan ini sudah bukan merupakan hal yang patut diherankan dewasa ini. 'Amplop' yang diberikan kepada jaksa atau hakim seakan telah menjadi syarat sah suatu peradilan. Hal ini merupakan sebuah ironi sebab idealnya, pengadilan adalah lembaga yang berusaha mencari dan menjunjung keadilan. Harta yang didapatkan hakim tersebut (dari hasil suap) tidak akan berbarokah dan membahagiakannya. Hal ini senada dengan apa yang dialami si penyuap. Walaupun ia terbebas dari perkaranya di pengadilan, akan tetapi ia menderita kerugian materi yang tidak sedikit setelah menyuap hakim.

Berbeda dengan al-ghulul, term satu ini lebih bermakna suap (atau yang biasa disebut risywah). Suap biasanya diberikan dalam suatu praktik peradilan kepada pihak-pihak yang cukup berpengaruh, semisal jaksa, hakim, maupun pengacara. Karena itulah, praktik ini dilakukan dengan cara sembunyi-sembunyi. Tujuan yang diharapkan si penyuap dalam aktivitas ini tidak lain adalah memenangkan perkara ataupun memperoleh kemudahan dalam menyelesaikan sesuatu. Sesuatu yang ingin diselesaikannya bisa merupakan hal yang halal maupun haram. Namun, terlepas dari hukum hal yang ingin dicapai, kehadiran ad-dalwu dalam usaha mencapai hal tersebut sudah memberikan nilai minus. Tidak ada penjabaran mengenai hukuman praktik ini dalam Alquran. Tetapi, penyajian fi il nahi dalam bahasan ini cukup merepresentasikan bahwa praktik ini haram dilakukan, karena akan merugikan diri sendiri dan orang lain.

\section{Surat al-Maidah ayat 33}

Sesungguhnya pembalasan terhadap orang-orang yang memerangi Allah dan Rasul-Nya dan membuat kerusakan di muka bumi, hanyalah mereka dibunuh atau disalib, atau dipotong tangan dan kaki mereka dengan bertimbal balik, atau dibuang dari negeri (tempat kediamannya). yang 
demikian itu (sebagai) suatu penghinaan untuk mereka didunia, dan di akhirat mereka beroleh siksaan yang besar, (QS:5:33)

\section{Asbab al-Nuzul}

Sebab turun ayat ini adalah peristiwa di Madinah saat ada beberapa orang dari bani U'kal dan Urainah yang menyampaikan keinginan untuk masuk Islam kepada Rasulullah SAW. Namun, mereka mengatakan bahwa mereka tidak merasa nyaman tinggal di Madinah. Nabi pun memerintahkan seorang penggembala untuk menemani beberapa orang tersebut keluar dari Madinah. Nabi juga menyertakan seekor unta yang akan menjadi alat transportasi mereka serta mengizinkan mereka meminum susu dari unta tersebut. Berangkatlah beberapa orang tersebut didampingi seorang penggembala.

Di tengah perjalanan, orang yang berniat masuk Islam tersebut kemudian membunuh si penggembala yang menemani mereka dan membawa lari unta yang merupakan milik negara yang berasal hasil zakat. Mendengar kabar tersebut, Rasulullah kemudian mengutus pasukan untuk memburu dan mengejar pembunuh dan perampok yang telah berlaku jahat tersebut. Setelah tertangkap, mereka mendapat hukuman cungkil mata, dan dipotong tangan dan kaki secara silang hingga hukuman mati. Mereka mendapat hukuman plus-plus tersebut sebab melakukan kejahatan yang juga plus, yakni membunuh dan merampok, serta menghianati kepercayaan dan fasilitas yang telah diamanahkan Rasulullah SAW. Hukuman mati biasanya diberikan kepada mereka yang mengganggu ketentraman masyarakat luas dan membunuh. Sedangkan hukuman salib sampa mati diberlakukan bagi orang yang mengganggu, membunuh, dan merampok. Hukum potong tangan ditujukan bagi orang yang hanya melakukan perampasan harta. Hukuman diasingkan dalam ayat ini bisa diartikan dengan hukuman kurungan atau penjara. ${ }^{21}$

\section{Tafsiran Ayat}

Term berikutnya yang terindikasi sebagai term korupsi dalam Alquran adalah hirabah(perampokan). Menjelaskan hal tersebut, Hakim Muda Harahap menguraikan bahwa arti lain dari kata yuharibuna apabila dirunut ke asal bentukan awalnya dari tsulatsi mujarrad maka ia bermakna seseorang yang merampas harta dan meninggalkannya tanpa bekal apa pun. ${ }^{22} \mathrm{Hal}$ yang

\footnotetext{
${ }^{21}$ Dasuki (dkk.), 1991: 428.

${ }^{22}$ Hakim Muda Harahap, Ayat-ayat Korupsi, (Yogyakarta: Gama Media, 2009): 80-82.
} 
sama juga datang dari pandangan sebagian ahli fiqh mengenai kata hirabah. Menurut mereka orang yang melakukan tindakan hirabah sebagai qathi'u althariq atau penyamun dan al-sariq al-kubraatau pencurian besar. Dengan kata lain, makna hirabah di sini adalah seseorang yang merampok harta orang lain. Pengertian seperti inilah yang kemudian sering digunakan oleh ulama untuk memaknai kata yuharibuna dalam surat al-Maidahayat 33 tersebut. $^{23}$

Melihat kronologi asbabun nuzul di atas, agaknya orang-orang tersebut memang tidak memiliki niat yang ikhlas dan teguh untuk memeluk Islam. Hal ini, paling tidak terbukti dengan permintaan mereka yang cukup besar dan mengada-ada pada Nabi. Atau bahkan, wajar jika dikatakan bahwa niat mereka sejak awal tidak lain adalah untuk merampok dan membunuh, namun dengan kedok masuk Islam agar memudahkan tercapainya rencana mereka. Dugaan ini diperkuat dengan apa yang diungkapkan al-Maraghi bahwa setelah membunuh si penggembala dan membawa lari unta tersebut, beberapa orang tersebut kemudian kembali pada kaumnya dan menyatakan bahwa mereka kembali kafir. ${ }^{24}$ Ayat ini secara umum melarang manusia untuk menciptakan chaos di muka bumi, khususnya chaos yang sifatnya perampasan hak-hak orang lain, seperti perampasan harta dan nyawa. Potongan ayat yang menunjukkan objek harb (memerangi) Allah SWT dan Rasul-Nya masih bersifat abstrak. Hal ini dikonkritisasi dengan potongan selanjutnya, yakni membuat kerusakan di muka bumi yang sebenarnya masih memiliki dimensi yang demikian luas. Barangkali, chaos yang dimaksud dalam ayat ini adalah suatu tindakan yang mengancam lima hal yang harus dijaga dan dilindungi (yakni jiwa, harta, akal, keturunan, dan harta)

Hukuman bagi pelaku al-muharabah ini disebutkan secara tegas dan konkrit dalam al-Qur`an. Al-Qur`an juga membahasakan bahwa orang yang melakukan praktik tersebut mendapat kesengsaraan di dunia dan di akhirat. Kesengsaraan di dunia agaknya sudah bisa dipastikan sebab ia telah menciptakan kekacauan secara luas. Secara otomatis, hukum yang mengancamnya jauh lebih berat dibanding perbuatan tidak terpuji yang objeknya individu. Al-Maraghi menambahkan bahwa untuk katagori ini, seorang yang ingin bertaubat bisa melunasi taubatnya dengan keteguhan hati

${ }^{23}$ Abdul Halim Hasan Binjai, Tafsir al-Abkam, (Jakarta: Kencana, 2006): 384.

${ }^{24}$ Al-Maraghi, 2006: 189. 
dan mengembalikan semua apa yang pernah diambilnya. Selain itu, ia pun harus mendapat maaf dari sekelompok orang yang telah dirugikannya.

\section{Surat al-Maidah ayat 38}

Laki-laki yang mencuri dan perempuan yang mencuri, potonglah tangan keduanya (sebagai) pembalasan bagi apa yang mereka kerjakan dan sebagai siksaan dari Allah. dan Allah Maha Perkasa lagi Maha Bijaksana. (QS:5:38)

\section{Asbab al-Nuzul}

Pada zaman Rasulullah SAW ada seseorang perempuan yang melakukan pencurian. Kemudian perempuan itu dipotong tangannya, sebagaimana yang diperintahkan Allah SWT pada ayat ke-38 ini. Pada suatu waktu dia bertanya kepada Rasulullah SAW: " adakah tobatku kamu terima, wahai Rasulullah?" sehubungan dengan pertanyaan itu Allah SWT menurunkan ayat ke 39 yang dengan tegas memberikan keterangan, bahwa Allah SWT selalu menerima tobat seseorang yang telah melakukan kejahatan, asalkan dia bersedia untuk memperbaiki diri, mengganti perbuatan jahat itu dengan perbuatan yang baik.

Ibn Katsir dalam tafsirnya menjelaskan sebuah riwayat yang bersumber dari Abdullah bin Amr, ia mengatakan bahwa ayat ini turun berkenaan dengan seorang wanita yang mencuri, maka datanglah orang yang kecurian itu dan berkata pada Nabi SAW. "Wahai Nabi, wanita ini telah mencuri perhiasan kami". Maka kaum wanita itu berkata "Kami akan menebus curiannya." Nabi bersabda, "Potonglah tangannya!" Kaumnya berkata, "Kami akan menebusnya dengan lima ratus dinar." MakaNabi SAW. pun bersabda, "Potonglah tangannya!" Maka dipotonglah tangan kanannya. Kemudian wanita itu bertanya. "Ya Rasul, apakah ada jalan untuk aku bertobat?" Jawab Nabi SAW," "Engkau kini telah bersih dari dosamu sebagaimana engkau lahir dari perut ibumu”. Kemudian turunlah surat alMaidah ayat 38 tersebut. $^{25}$

\section{Tafsiran Ayat}

Kata 'saraqa'di dalam ayat secara etimologi bermakan " $a k h d z u$ ma li al-ghairi khufyatan" (mengambil harta orang lain secara sembunyisembunyi). ${ }^{26}$ Sedangkan secara terminologis kata 'mencuri' (al-sarq) terlebih dahulu dibagi menjadi dua bagian, yaitu pencurian besar dan kecil. Pencurian

\footnotetext{
25Ibn Katsir, 1986: 94.

26Al-Munawwir, 1997: 628.
} 
besar merupakan arti lain dari term hirabah sebagaimana penulis jelaskan pada term sebelumnya. Sedangkan definisi tentang pencurian kecil, beberapa ulama memiliki makna yang bervariasi, yaitu (a) mengambil harta orang lain dengan sembunyi-sembunyi, yaitu harta yang cukup terpelihara menurut kebiasaannya, (b) mengambil harta orang lain secara sembunyi-sembunyi dengan jalan menganiaya, (c) mengambil harta orang lain dengan sembunyisembunyi, yaitu harta yang bukan diamanatkan padanya. ${ }^{27}$ Dari sini dapat disimpulkan bahwa yang dimaksud dengan al-sarq adalah mengambil harta orang lain yang bukan miliknya dengan jalan sembunyi-sembunyi tanpa kerelaan pemiliknya.

Budaya potong tangan sebagai hukuman bagi siapapun yang mencuri ini senyatanya merupakan tradisi jahiliyah yang diadopsi oleh Islam dengan beberapa perubahan komplementif. ${ }^{28}$ Dalam tafsir Ahkamnya, Syaikh Abdul Halim Hasan menegaskan bahwa ada dua macam pencurian, yakni pencurian besar dan pencurian kecil.Sayangnya, Syaikh Abdul Halim Hasan tidak memberikan eksplorasi yang cukup memadai terhadap ciri-ciri dan karakteristik pencurian besar. Ia agakanya lebih tertarik terhadap apa yang diistilahkannya sebagai pencurian kecil. Hal ini setidaknya terbukti dengan eksplorasi yang cukup luas mengenai pencurian kecil. Ia hanya menyebutkan bahwa hukuman bagi pelaku pencurian besar adalah hukuman mati, atau potong tangan dengan sistem disalib. Jika dibandingkan dengan tafsir alMaidah ayat 33, maka pencurian besar ini adalah pencurian yang mengakibatkan kekacauan secara luas, tidak hanya pada level individu.

Syaikh Abdul Halim Hasan mengatakan bahwa pencurian kecil adalah pencurian secara sembunyi-sembunyi terhadap harta yang bukan merupakan diamanahkan kepada orang yang mencuri. Ia juga menegaskan bahwa ada dua macam hukuman dalam pencurian kecil ini, yakni hadd (potong tangan) dan ta 'dzir (diasingkan, didera, dan dipenjara). Karakteristik pencurian tersebut kemudian berpengaruh besar terhadap jenis hukuman yang harus diterima orang tersebut. Syaikh Abdul Halim Hasan mengutip salah satu hadist yang mengatakan bahwa tidak ada hukuman hadd bagi orang yang menghianati amanah. Berangkat dari inilah ia kemudian menyimpulkan bahwa hukuman hadd (seperti yang disebutkan dalam ayat ini) hanya berlaku bagi orang yang mencuri hak miliki orang lain dan bukan harta yang

${ }^{27}$ Binjai, 2006: 375.

${ }^{28}$ Ibnu Katsir, 1986: 91 
diamanahkan pada pelaku pencurian tersebut. Dengan demikian, dapat difahami bahwa hukuman yang paling representatif untuk para koruptor adalah dipenjara. ${ }^{29}$

Tafsir terbitan UII menambahkan bahwa suatu hukuman terhadap pencurian ini baru bisa dilaksanakan jika pelaku sudah mengakui atau sudah ada bukti dan saksi yang sangat menguatkan dan terjamin validitasnya. Akan tetapi, hukuman ini masih mungkin bisa digagalkan jika korban yang bersangkutan memberikan maaf pada pelaku, biasanya disertai beberapa persyaratan, seperti mengembalikan harta yang dicuri. ${ }^{30}$ Ulama' masih berbeda pendapat mengenai jumlah (nisab) barang curian yang menyebabkan seseorang harus menjalani potong tangan. ${ }^{31}$ Namun hampir semua ulama tafsir menyetujui bahwa tujuan adanya hukuman ini adalah menimbulkan efek jera pada sang pelaku dan pada orang lain.

Jika ditinjau dalam konteks ayat ini pada masa turunnya, maka ayat ini agaknya lebih menekankan pada pencurian yang dilakukan orang yang tidak memiliki jabatan. Dalam artian, pelaku pencurian ini bukanlah orang yang memanfaatkan kesempitan dalam kesempatan dan fasilitasnya sebagai seorang yang memangku jabatan atau apa yang lazim kita sebut korupsi.

${ }^{29}$ Binjai, 2006: 377.

${ }^{30}$ Dasuki, 1991: 437.

${ }^{31}$ Ibnu Katsir, 1986:92-93. Nishab adalah nilai harga minimal yang bila terpenuhi, maka pencurian itu mewajibkan dilaksanakannya potongtangan. Seandainya barang yang dicuri itu nilainya kecil dan masih di bawah harga nisab itu, maka tidak termasukhal itu.Namun para ulama tidak secara tepat menyepakatibesarnya nishab itu. Jumhur ulama diantaranya al-Malikiyah, alSyafi iyah dan al-Hanabilah sepakat bahwa nishab pencurian itu adalah $1 / 4$ dinar emas atau 3 dirham perak.Nilai ini setara dengan harga 4,45 gram emas murni. Jadi bila harga emas murni 24 per gramnya Rp.100.000,-, maka satu nisab itu adalah Rp. 100.000,- x4,45 gram = Rp. 445.000,-. Bila benda yang dicuri oleh seseorang harganya setaraatau lebih dari Rp. 445.000,-, dia sudah bisa dipotongtangannya. Dalilnya adalah sabda Rasulullah SAWdari Aisyah ra. ,'Tangan pencuri dipotong bila nilainya $1 / 4$ dinarke atas". HR. Bukhari, Muslim dan ashabu kutub sittah. Dari Abdullah bin Umar ra. bahwa Rasulullah SAWmemotong tangan pencuri mijan yang nilainya 3dirham". HR. Bukhari, Muslim, Abu Daud, at-Tirmizydan an-Nasai.

Sedangkan al-Hanafiyah menetapkan bahwa nishabpencurian itu adalah 1 dinar atau 10 dirham atau yangsenilai dengan keduanya dengan berdalil pada hadits Rasulullah SAW,:"Tidaklahdipotong selama nilainya di bawah 10 dirham." HR Ahmad.Juga hadits lainnya,"Tidak dipotong tangan kecuali senilai 1dinar atau 10 dirham". HR. At-Thabarani. Juga hadits lainnya,"Tidaklah tangan pencuri itu dipotongkecuali nilainya seharga "mijan" dimana saat itu seharga 10dirham". HR. Abu Syaibah.

Bila kita cermati latar belakang perbedaan itu sebenarnya hanyalah berkisar pada penetapan hargamijan. Dimana jumhur ulama sepakat bahwa harganyasaat itu 1/4 dinar. Sedangkan al-Hanafiyah menganggap harganya saat itu 1 dinar. Lihat. Ahmat Sarwat, Kajian Ayat Abkam; Ayat-ayat Alquran yang Mengandung Hukum Syari'at, (Jakarta: Du Center, 2009), Cet ke-2: 42 
Ada beberapa perbedaan dalam menyikapi hukuman kepada pelaku pencurian ini, juga perbedaan dalam nominal harta yang dicuri sehingga menyebabkan si pencuri harus menjalani hukum potong tangan. Perbedaan tersebut umumnya disebabkan berbedanya sudut pandang yang dipakai oleh masing-masing ulama`. Tetapi, jumhur ulama` menyatakan bahwa harta yang dicuri sekurang-kurangnya adalah seperempat dinar. Sedangkan mengenai hukuman, maka di sini ulama` berpendapat bahwa pada pencurian pertama, tangan kananlah yang dipotong. Ukuran memotong ini adalah sampai pergelangan tangan. Jika masih mengulangi kesalahan tersebut, maka kaki kirinya yang akan dipotong, dilanjutkan dengan tangan kiri, kemudian kaki kanan. Hukuman terakhir dalam pencurian ini adalah pengasingan. ${ }^{32}$

\section{Menelaah Hukuman bagi Koruptor}

Semenjak periode awal Islam hingga dewasa ini di dalam kitab-kitab fiqh klasik belum ditemukan suatu rumusan yang jelas tentang korupsi. ${ }^{33}$ Tetapi substansi-substansi yang tercakup dalam pengertian korupsi telah banyak dibicarakan oleh para ulama bahkan sebagaimana Alquran dan hadis secara implisit telah menyinggungnya secara umum atau garis besarnya yaitu dengan menggunakan beberapa term di atas.

Di dalam hadis, ditemukan hukuman bagi pelaku ghulul (mencuri rampasan perang), di antaranya:

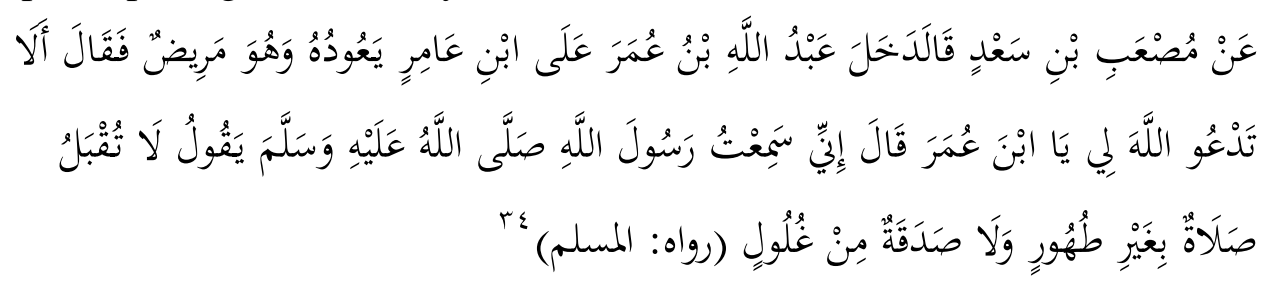

Dari Mush'ab ibn Sa'd. Ia berkata, Abdullah ibn 'Umar masuk ke rumah Ibn 'Amir untuk menjenguknya karena sakit. Kemudian Ibn 'Amir berkata, "Mengapa engkau tidak berdoa kepada Allah untuk kesembuhanku, hai Ibn Umar?" Ibn Umar berkata, "Aku mendengar Rasulullah saw. bersabda: "Shalat tanpa bersuci tidak diterima dan begitu juga sedekah dari hasil ghulul." (HR: Muslim)

Ada juga hadis riwayat Abu Daud berbunyi:

\footnotetext{
${ }^{32}$ Dasuki, 1991: 434

${ }^{33}$ Duski Ibrahim, "Perumusan Fikih Anti Korupsi” dalam Suyatno,ed, Korupsi, Hukum dan Moralitas Agama, (Yogyakarta: Gama Media, 2006): 128.

${ }^{34}$ CD-ROOM, No. Hadis. 329.
} 


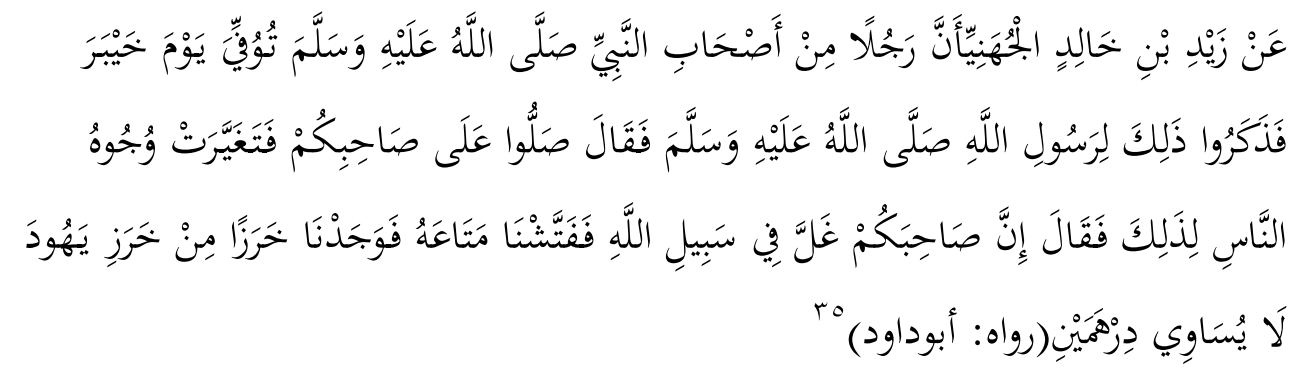

Dari Zaid ibn Khalid al-Juhaini, bahwa seorang laki-laki shahabat Nabi mati pada perang Khaibar, kemudian sampai berita pada Nabi, lalu Nabi bersabda: "Shalatkanlah saudara kamu". Maka berubahlah wajah para shahabat karena kaget. Lalu Nabi bersabda: "sesungguhnya saudara kamu telah korup dalam perang di jalan Allah, maka periksalah barangnya”. Ternyata mereka menemukan perhiasan yang tidak seniai dengan dua dirham". (HR.Abu Daud)

Namun kedua hadis tersebut hanya memberi sanksi moral para para pelaku ghulul, yaitu dengan tidak menyolatkan jenazahnya ketika mati dan Allah SWT tidak menerima shadaqah dari hasil ghulul, bukan sanksi pidana yang tegas.

Oleh karena itu, selain mendasarkan kepada nash-nash Alquran dan sunah, maka perumusan fiqh anti korupsi ini haruslah mengacu kepada paling tidak dua kerangka kaidah fiqh, yaitu, pertama: "Perkara dominan dari pertimbangan kemaslahatan dan kemafsadatan." Kaidah ini senada dengan "Mencegah bahaya lebih utama dari pada menarik datangnya kebaikan."

Terlihat bahwa tindakan korupsi memiliki sisi maslahah dan mafsadatnya. Sisi maslahatnya misalnya ialah perbuatan itu dapat menguntungkan si pelaku, keluarga, partai, atau kelompok-kelompok tertentu yang menikmati fasilitas atau hasil-hasilnya. Ini jelas merupakan suatu maslahah duniawiyah. Tetapi sisi kemafsadatannya justru lebih besar karena dengan korupsi maka berarti mengorbankan kepentingan orang banyak. Ini merupakan suatu kezaliman, pengkhianatan yang berarti menyia-nyiakan kepercayaan orang banyak. ${ }^{36}$

Kaidah kedua adalah:

Apapun yang dilakukan di dunia ini haruslah dikaitkan dengan konskuensinya di akhirat.

${ }^{35} \mathrm{CD}$-ROOM, No. Hadis. 2335.

${ }^{36}$ Abdul Haq, dkk, Formulasi Nalar Fiqh, (Surabaya: Kalista, 2006), Juz I: 237. 
Sejauh ini tindakan korupsi telah mengorbankan kemaslahatan ukhrawiyah, suatu nilai yang tidak dapat dilepaskan ketika melakukan setiap perbuatan menurut ajaran Islam. ${ }^{37}$ Tentu hal itu tidak bisa dipisahkan antara kehidupan materialistis dengan sikap hidup yang hedonis dan glamor, sehingga pada dimensi-dimensi tertentu nilai-nilai ukhrawi mulai terlupakan.

Selama ini, apa yang diupayakan oleh ahli fiqh (fuqaha) merupakan langkah dalam melegitimasi setiap gerak-gerik dimensi kehidupan agar selaras dengan tujuan maqashid al-syari'ah. Sebagaimana telah masyhur, tujuan utama syari'at Islam (maqasid al-syari'ah) ialah upaya untuk menjaga dan melindungi dimensi penting dari manusia. ${ }^{38}$ Perlindungan ini dijelaskan oleh asy-Syatibi dalam al-Muwafaqat memiliki lima tujuan yakni perlindungan terhadap agama (hifdz ad-din), perlindungan terhadap jiwa (hifdz an-nafs), perlindungan terhadap akal (hifdz al-'aql), perlindungan terhadap keturunan (hifdz an-nasab), dan perlindungan terhadap harta (hifdz al-mal). ${ }^{39}$

Tindakan korupsi jelas merupakan penyelewengan terhadap tujuan kelima, yakni perlindungan terhadap harta (hifdz al-mal). Apabila contoh yang populer perbuatan melawan tujuan perlindungan terhadap harta (hifdz al-mal) adalah mencuri milik perorangan, maka korupsi sebagai kejahatan mencuri harta milik bangsa dan negara lebih layak lagi untuk dicatat sebagai pelanggaran yang sangat serius terhadap prinsip perlindungan terhadap harta (hifdz al-mal). Korupsi bukanlah pencurian biasa dengan dampaknya yang bersifat individu akan tetapi korupsi merupakan bentuk pencurian besar dengan dampaknya yang bersifat sosial. Bahkan ketika korupsi sudah merajalela dalam suatu negara sehingga negara itu nyaris bangkrut dan tak berdaya dalam mensejahterakan kehidupan rakyatnya, tidak mampu menyelamatkan mereka dari ancaman gizi buruk dan busung lapar yang mendera, maka korupsi lebih jauh dapat dianggap sebagai ancaman bagi tujuan syari'at dalam melindungi jiwa manusia (hifdz an-nafs).

\footnotetext{
${ }^{37}$ Ibrahim, 2006: 137-138.

${ }^{38}$ Lengkapnya, tujuan tersebut menurut al-Syatibi ada tiga. Pertama. Tujuan yang sifatnya paling utama (dlaruriyyah), yaitu sesuatu yang harus ada demi tegaknya kehidupan manusia. Kedua. Tujuan yang sifatnya kebutuhan (bajijyyah), yaitu segala sesuatu yang diperlukan oleh manusia untuk menghindarkan diri dari kesulitan. Ketiga. Tujuan yang sifatnya kesempurnaan/kebaikan (tabsiniyyah), yaitu mempergunakan segala yang layak dan pantas yang dibenarkan oleh adat kebiasaan yang semua ini dicakup oleh bagian makarim al-akblak. Lihat Abu Ishaq al-Syatibi, alMuwaffaqat fi Ushul al-Syari'ah, Juz II, (Bairut: Dar al-Kutub al-Ilmiyyah, 2004): 7-9.

${ }^{39}$ Al-Syatibi, 2004: 9.
} 
Sanksi hukum potong tangan tentu saja tidak dapat diberlakukan, sebab korupsi berbeda dengan tindak pidana pencurian yang telah jelas hukumnya dalam nash (Alquran) meskipun sama-sama merupakan pelanggaran terhadap Hifdzul mal akan tetapi korupsi tidak ditemukan hukumnya dalam nash. Namun demikian, bukan berarti tindak pidana korupsi bisa lepas dari hukuman, karena perbuatan tersebut jelas-jelas telah mengganggu kemaslahatan umum, sehingga dapat dikategorikan sebagai jarimah ta'dzir, yang dalam pelaksanaannya mungkin menyamai atau bahkan melebihi sanksi hukuman Qishash atau hadd. ${ }^{40}$

Syara' tidak menentukan macam-macam hukuman untuk tiap-tiap jarimah ta'dzir tetapi hanya menyebutkan sekumpulan hukuman dari yang seringan-ringannya sampai kepada yang seberat-beratnya. Dalam hal ini penguasa diberi kekuasaan untuk menentukan hukuman-hukuman sesuai kepentingan masyarakat, dan tidak boleh bertentangan dengan ketentuanketentuan syari'at dan prinsip-prinsip yang umum.

Dengan demikian, semua undang-undang dan peraturan atau hukuman-hukuman yang telah diberlakukan pemerintah Indonesia terhadap semua tindak pidana di antaranya korupsi sebagimana yang tertuang dalam UU Nomor 31 Tahun 1999 dan yang telah disempurnakan oleh UU Nomor 20 Tahun 2001 yang hal ini tergolong ke dalam jarimah ta'dzir, ${ }^{41}$ selama tidak bertentangan dengan prinsip-prinsip syari'at dan dapat mewujudkan maslahatul ummah, bisa dikatakan telah sesuai dengan prinsip ta'dzir dalam hukum pidana Islam, yang pada prinsipnya memang merupakan hak pemerintah dalam rangka menjaga kemaslahatan masyarakat yang dipimpinnya.

Salah satu hal terpenting yang harus ditegakkan dalam penegakan hukum Islam adalah memutuskan perkara berdasarkan prinsip keadilan dan persamaan terhadap siapapun. Apabila seorang penegak hukum tidak memiliki moralitas dan integritas yang tinggi, maka ia akan memutuskan

\footnotetext{
${ }^{40}$ Ibrahim, 2006: 139.

${ }^{41}$ Pidana mati untuk koruptor di Indonesia bisa diberlakukan, bila mengacu kepada UU RI No. 20 Tahun 2001 tentang Perubahan Atas UU No. 31 Tahun 1999 Tentang Pemberantasan Tindak Pidana Korupsi. Pasal 2 Ayat 2 menyebutkan Dalam hal tindak pidana korupsi sebagaimana dimaksud dalam ayat (1) dilakukan dalam keadaan tertentu, pidana mati dapat dijatuhkan. Yang dimaksud dengan keadaan tertentu adalah apabila tindak pidana korupsi itu dilakukan bila keadaan negara dalam bahaya, bencana alam nasional, pengulangan tindak pidana korupsi, atau pada waktu negara dalam keadaan krisis ekonomi dan moneter.(http://cetak.fajar.co.id/kolom/print.php?newsid=857).
} 
perkara sesuai dengan pertimbangan hawa nafsu, pribadi maupun kelompok, sehingga keputusan yang diambil merugikan salah satu pihak yang berperkara. Oleh karena itu moralitas utama seorang penegak hukum pidana Islam harus dibangun diatas prinsip-prinsip keadilan sebagaimana firman Allah SWT:

Sesungguhnya Allah menyuruh kamu menyampaikan amanat kepada yang berhak menerimanya, dan (menyuruh kamu) apabila menetapkan hukum di antara manusia supaya kamu menetapkan dengan adil. Sesungguhnya Allah memberi pengajaran yang sebaik-baiknya kepadamu. Sesungguhnya Allah adalah Maha mendengar lagi Maha melihat. (QS:4:58)

Oleh karena itu, hukum harus ditegakkan tanpa pandang bulu, apakah dilakukan oleh pejabat (pelaku tindak pidana korupsi) yang "separtai" atau rakyat kecil. Setiap individu mempunyai nilai yang sama dihadapan hukum. Disisi lain, rakyat wajib menaati pemerintah, karena agama telah memerintahkan hal tersebut selama dalam hal yang ma'ruf. ${ }^{42}$

Selain hukum pidana, juga terdapat sanksi moral dilakukan dengan terus menerus menanamkan unsur moralitas kepada koruptor, melalui pendidikan atau memberi pertimbangan khusus menyangkut suatu kedudukan dalam masyarakat dan jabatan dalam pemerintahan. Sebab, orang yang layak dijadikan pemimpin adalah orang yang dalam setiap tindakannya selalu memperhatikan kepentingan orang banyak, sesuai dengan kaidah fiqh yang berbunyi "Kebijakan pemimpin sesuai dengan kemaslahatan rakyat yang di pimpinnya".

\section{PENUTUP}

Korupsi sebagai sebuah tindak kejahatan extra-ordinary crimes memang tidak disebut secara eksplisit oleh Alquran. Tetapi beberapa term seperti ghulul, suht, sarq, hirabah, dan lain sebagainya ditinjau dari konteks dan sudut pandang interpretasi yang ditelusuri maka beberapa term tersebut dirasa cukup mewakili gagasan Alquran mengenai tindakan korupsi. Oleh karenanya, apa yang dihasilkan dari pengamatan korupsi dalam Alquran

${ }^{42}$ Ayat yang memerintahkan untuk menta'atai pemimpin di antaranya surat an-Nisa' ayat 59, berbunyi: Hai orang-orang yang beriman, taatilah Allah dan taatilah Rasul (Nya), dan ulil amri di antara kamu. kemudian jikea kamu berlainan Pendapat tentang sesuatu, Maka kembalikanlah ia kepada Allah (al- Quran) dan Rasul (sunnahnya), jika kamu benar-benar beriman kepada Allah dan hari kemudian. yang demikian itu lebib utama (bagimu) dan lebih baik akibatnya. 
diharapkan bisa memberikan kontribusi dalam merumuskan langkah solutif untuk mencegah dan memberantas tindakan korupsi tersebut.

Adapun mengenai hukuman bagi pelaku korupsi, yang paling cocok menurut penulis adalah hukuman jarimah ta'dzir yang dalam pelaksanaannya mungkin menyamai atau bahkan melebihi sanksi hukuman hadd. Sebab sanksi hukum potong tangan tidak dapat diberlakukan, karena korupsi berbeda dengan tindak pidana pencurian yang telah jelas hukumnya dalam Alquran. Dalam hal ini penguasa diberi kekuasaan untuk menentukan hukuman-hukuman sesuai kepentingan masyarakat, dan tidak boleh bertentangan dengan ketentuan-ketentuan syari'at dan prinsip-prinsip yang umum. Seperti menerapkan UU Nomor 31 Tahun 1999 dan yang telah disempurnakan oleh UU Nomor 20 Tahun 200.

Dengan demikian, harapan penulis melalui tulisan ini, supremasi hukum yang telah dilaksanakan selama ini perlu untuk kembali diperbaiki dengan melihat sosial justice. Oleh karenanya supremasi hukum yang terkesan "bobrok" selama ini perlu udara segar adanya sebuah rekontruksi, yang besar harapan penulis, rumusan fiqh anti korupsi ini juga dapat dijadikan sebagai tawaran langkah-langkah solutif pemberantasan korupsi dengan tetap memperhatikan nilai-nilai pluralitas.

\section{DAFTAR PUSTAKA}

Asmara, M. Reinterpretasi Makna Jihad Dan Teroris. Al-ISTINBATH : Jurnal Hukum Islam, 1(1), (2016). doi:http://dx.doi.org/10.29240/jhi.v1i1.87

Binjai, Abdul Halim Hasan, Tafsir al-Ahkam, Jakarta: Kencana, 2006

Baidlawi, Ahmad, "Pemberantasan Korupsi dalam Persepektif Islam", dalam Jurnal Esensia, Vol. 10, No. 2, Juli, 2009: 8.

Crowther, Jonathan,ed., Oxford: Advanced Learners Dictionary,1995

Dasuki, Hafidz dkk., al-Qur`an dan Tafsirnya, Yogyakarta: UII Press, 1991 Harahap, Hakim Muda, Ayat-ayat Korupsi,Yogyakarta: Gama Media, 2009

Hamzah, Andi, Pemberantasan Korupsi Melalui Hukum Nasional dan Internasional, Jakarta: Raja Grafindo Persada, 2005

Haikal, Muhammad Husain, Sayyidina Umar bin Khattab, Jakarta: Litera Antar Nusa, 2003: 665.

(http://cetak.fajar.co.id/kolom/print.php?newsid=857).

Haq, Abdul, dkk, Formulasi Nalar Fiqh,Surabaya: Kalista, 2006, Juz I 
Irfan, M. Nurul, 2011, Korupsi dalam Hukum Pidana Islam, Jakarta: Amzah, 2011

Ibn Katsir, Tafsir Alquran al-Karim, Terj. Salim Bahraesi dan Said Bahraesi,Surabaya: Bina Ilmu, 1986, Jilid II

Ibrahim, Duski, "Perumusan Fikih Anti Korupsi" dalam Suyatno,ed, Korupsi, Hukum dan Moralitas Agama, Yogyakarta: Gama Media, 2006

Klitgaard, Robert dkk., Penuntun Pemberantasan Korupsi dalam Pemerintahan Daerah terj. Hermoyo, Jakarta: Yayasan Obor Indonesia, 2002

Al-Maghari, Tafsir al-Maghari, Bairut: Dar al-Kutub al-Ilmiyyah, 2006: 98.

Al-Munawwir, Ahmad Warson, al-Munawwir,Surabaya: Pustaka Progresif, 1997

S.H. Al-Alatas, Korupsi; Sifat, Sebab dan Fungsi terj. Nirwono, Jakarta; LP3ES, 1987: 2.

Syihab,Quraisy, Tafsir al-Misbah, Jakarta: Lentera Hati, 2002

Suratno, Chamamah, ed., Ensiklopedi al-Qur`an: Dunia Islam Modern, Yogyakarta: Bhakti Prima Yasa, 2003

Soesatyo, Bambang, Perang-perangan Melawan Korupsi, Jakarta: Ufuk Press, 2011

Sarwat. Ahmat, Kajian Ayat Ahkam; Ayat-ayat Alquran yang Mengandung Hukum Syari'at, Jakarta: Du Center, 2009, Cet ke-2

Al-Syatibi, Abu Ishaq, al-Muwaffaqat fi Ushul al-Syari'ah, Juz II, Bairut: Dar al-Kutub al-Ilmiyyah, 2004: 7-9.

Thaba 'i, Thaba', Tafsir al-Mizan,Beirut: Yayasan al-Г lami, t.th, Juz 2 Al-Zamakhsyari, Tafsir al-Kasyaf, Bairut: Dar al-Ilmiyyah, 1968, Juz III 